\title{
DISTRIBUTION AND MAINTENANCE OF VEGETATION ADJACENT TO HIGH VOLTAGE TRANSMISSION LINES, SOUTHERN BRAZIL
}

\author{
DuARTE, S. W. $.^{*}-$ MAÇANEIRO, J. P. ${ }^{2}-$ FEnILli, T. A. B $.^{1}-$ SCHORN, L. A. ${ }^{1}-$ BlunK, L. ${ }^{1}-$ \\ MEDEIROS, D. S. ${ }^{3}$ \\ ${ }^{I}$ Departamento de Engenharia Florestal, Universidade Regional de Blumenau, Box. 89030-000, \\ Blumenau, Brazil \\ ${ }^{2}$ Departamento de Engenharia Florestal, Universidade Federal do Paraná, Box. 80210-170, \\ Curitiba, Brazil \\ ${ }^{3}$ Departamento de manutenções, Companhia Estadual de Energia Elétrica do Rio Grande do \\ Sul, Box. 91410-400, Porto Alegre, Brazil \\ *Corresponding author \\ e-mail: swduarte0@gmail.com; phone: +55-47-3221-6043 \\ (Received 10 ${ }^{\text {th }}$ Nov 2019; accepted $24^{\text {th }}$ Mar 2020)
}

\begin{abstract}
Vegetation is the main cause of power outages; therefore, it is fundamental to carry out maintenance to prevent the interruption of electric power. In general, the maintenance of transmission lines is performed without previous studies on floristic composition. In this sense, it is necessary to establish the floristic composition and the factors that influence the establishment of the species to determine the best practices of maintenance. In this study, we evaluated which environmental and spatial factors influence species distribution in order to improve the maintenance of vegetation adjacent to high voltage transmission lines. The vegetation was sampled in 25 plots of $300 \mathrm{~m}^{2}$, distributed randomly and prioritizing the main span of the power transmission line. The main factors that influenced species distribution were elevation, leaf area and $\mathrm{Mg} / \mathrm{K}$ ratio, all associated with the spatial factor. Therefore, maintenance along transmission lines should prioritize species associated with higher elevations and leaf area, considering a risk height of 7 meters.
\end{abstract}

Keywords: Atlantic Forest, environmental variables, electrical energy, power outages, RDA

\section{Introduction}

The Atlantic Forest is the second largest tropical pluvial forest on the American continent, it covers approximately $1,300,000 \mathrm{~km}^{2}$ in Brazil, being more representative in the south (Ribeiro et al., 2011; Rocha and Silva, 2013). This unit includes different forest types, climatic zones and it presents high species richness and endemism (Rocha and Silva, 2013). The Atlantic Forest is currently fragmented, with only $11.7 \%$ of its original coverage (Ribeiro et al., 2011). These forests are priority areas for the conservation of biological diversity, due to the exploitation processes and advanced stage of degradation (Ribeiro et al., 2011; Silverio Neto et al., 2015).

The process of degradation of the Atlantic Forest is usually associated with logging and conversion of Forests to agricultural and livestock areas. In addition to these activities, the installation and maintenance of power transmission lines has been causing severe environmental damage. For example, vegetation removal to build power transmission lines exposing the soil to erosive processes, as well as fragmenting ecosystems and altering natural succession (Dupras et al., 2015). Among the aspects to be evaluated in the maintenance of power transmission lines, we have metal structures 
and the objects that can cause power cuts (e.g., arboreal vegetation) (Matikainen et al., 2016). Accidents associated with vegetation are common, both in the urban and rural areas, and it is fundamental to carry out maintenance to prevent the interruption of electric power (Ahmad et al., 2014).

Usually, previous monitoring for maintenance of transmission lines is performed by aerial and visual survey (Matikainen et al., 2016), without previous studies about the floristic composition under the transmission lines. Thus, the improvement of vegetation maintenance techniques can benefit the electrical companies and the consumer (e.g., costs and risks reduction) (Kuntz et al., 2002). In addition, the use of pruning and vegetation cutting techniques can minimize the impacts generated by transmission networks, reducing the loss of natural habitats and forest fragmentation (Young, 2010).

Regardless of the maintenance technique used, it should be considered that the vegetation maintains growth variations throughout the year (Lopes, 2013). Therefore, it is essential to analyze the floristic composition and density, annual increments and growth rates (Lopes, 2013). For example, species growth is associated with several factors, such as luminosity, elevation and soil properties (e.g., fertility, depth and soil types) (Jurinitz et al., 2013; Moraes et al., 2013; Maçaneiro et al., 2016, 2019). In this way, the relationship between environmental variations and floristic composition can positively affect the frequency and intensity of vegetation maintenance, directly influencing the practice and the cost for the company.

Therefore, it seems reasonable to evaluate the environmental and spatial factors that influence the distribution of species in order to determine the best practices of maintenance (e.g., pruning) of vegetation adjacent to the power transmission lines. Thus, the goal of this study was to evaluate the influence of environmental and spatial variables on the distribution of species of forest fragments adjacent to power transmission lines and to determine the best practices of maintenance.

\section{Material and Methods}

\section{Study area}

The object of the study is forest remnants in distinct stages of succession located in an area adjacent to the power transmission line. This transmission line was installed in 1978. Along these areas, the responsible company for the transmission line regularly performs maintenance in the vegetation. In general, pruning and removal of trees or branches that may cause a power outage are performed. The maximum height that the vegetation can be to the electrical cables is 7 meters.

The transmission line is $65 \mathrm{~km}$ long and it covers 14 municipalities in the state of Rio Grande do Sul, southern Brazil (Figure 1). The region is part of the Guaiba river basin and it presents an altitude variation between 90 and 600 meters.

The climate of the region, according to the classification of Köppen, is of the type humid subtropical - Cfa, without dry season and with hot summer. The annual mean temperature fluctuates between $9^{\circ} \mathrm{C}$ to $26^{\circ} \mathrm{C}$, annual mean precipitation from 1,600 to 2,200 mm, and relative humidity between 60 and 85\% (Alvares et al., 2013).

The geology of the region is formed by the Botucatu Formation and Serra Geral Formation, presenting sandstones and basalts, respectively. The predominant soils are Litholic Neosols and Regolithic Neosols (Brazilian Classification) (Santos et al., 2018), and in general have high fertility $(\mathrm{V} \%>70 \%)$. 

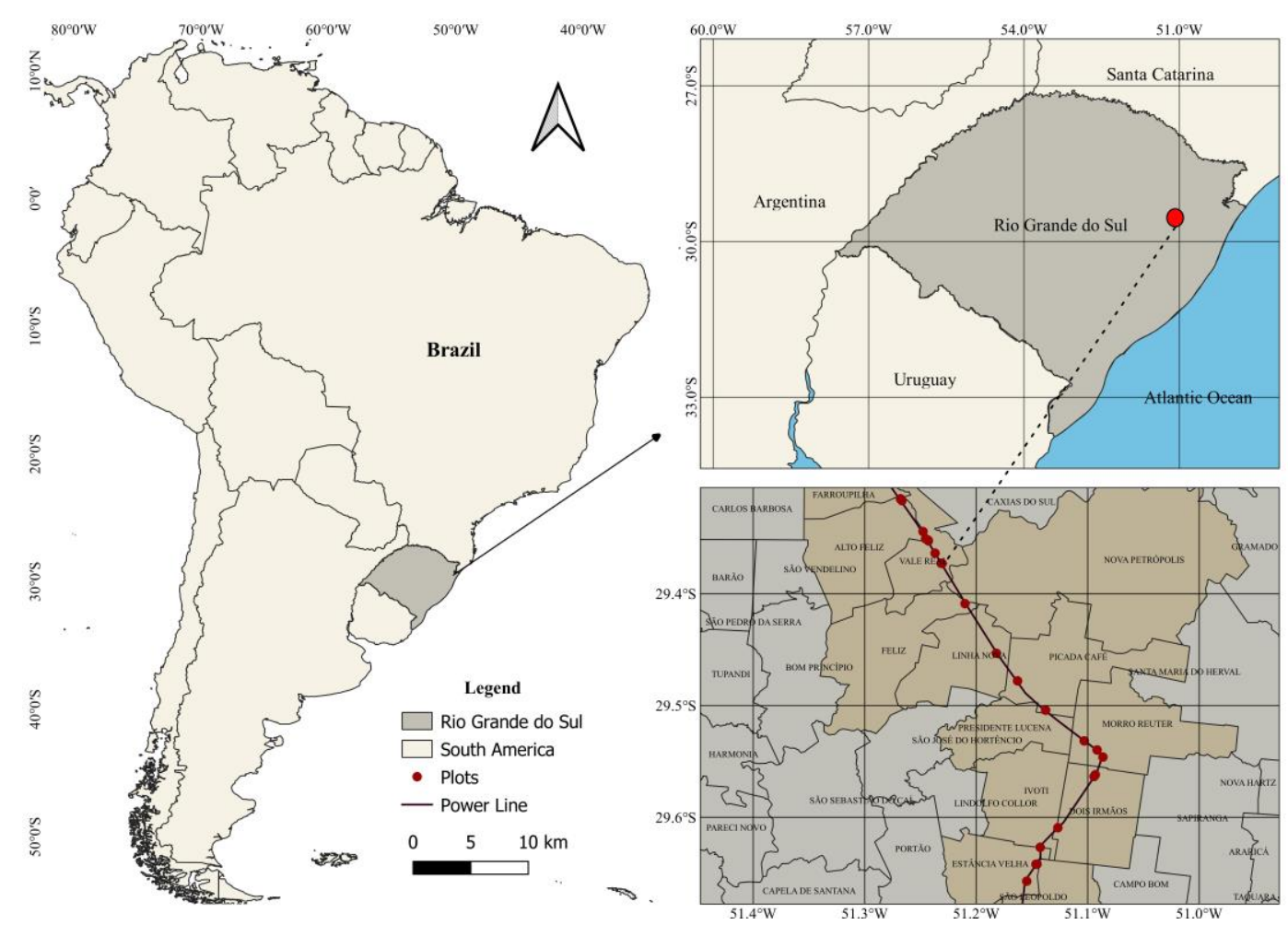

Figure 1. Location of the study area and plots in a power transmission line, southern Brazil

The predominant forest type is subtropical deciduous forest in distinct stages of succession. The structure of the vegetation that represents this formation is linked to the altitudinal and climatic variations, which according to Scipioni et al. (2013) guarantee heterogeneity of species in different Brazilian forest formations. Among the most representative species are Apuleia leiocarpa (Vogel) JF Macbr., Trichilia claussenii C. DC., Sorocea bonplandii (Baill.) WCBurger et al., Nectandra megapotamica (Spreng.) Mez.

\section{Data collection}

To characterize forest structure and determine environmental and spatial variables we sampled vegetation in 25 plots $300 \mathrm{~m}^{2}(10 \mathrm{~m}$ x $30 \mathrm{~m})$, parallel to the main span of the power transmission line. In each plot we sampled all arboreal individuals with diameter at breast height $-\mathrm{DBH} \geq 5 \mathrm{~m}$ and height $>1.3 \mathrm{~m}$. We collected the data between March/2018 and October/2018. We identified the collected botanical material by comparison with exsicates deposited in the Herbarium Dr. Roberto Miguel Klein and by consulting the taxonomic literature and the specialists the Universidade Regional de Blumenau (FURB).

To obtain the chemical properties of the soil, in each plot we collected soil samples in the depth of $0-20 \mathrm{~cm}$, i.e. we collected five points per plot and stirred the soil. Then, we stored the samples in plastic bags and sent them to the Laboratory of Soil Analysis of EPAGRI (Empresa de Pesquisa Agropecuária e Extensão Rural de Santa Catarina) to obtain the chemical variables: clay content $(\mathrm{m} / \mathrm{v}-\%), \mathrm{pH}$, phosphorus $\left(\mathrm{P}-\mathrm{mg} / \mathrm{dm}^{3}\right)$, potassium $\left(\mathrm{K}-\mathrm{mg} / \mathrm{dm}^{3}\right)$, organic matter $(\%)$, aluminum $\left(\mathrm{Al}-\mathrm{cmolc} / \mathrm{dm}^{3}\right)$, calcium $\left(\mathrm{Ca}-\mathrm{cmolc} / \mathrm{dm}^{3}\right)$, magnesium $\left(\mathrm{Mg}-\mathrm{cmolc} / \mathrm{dm}^{3}\right), \mathrm{SMP}$ index, potential acidity $(\mathrm{H}+\mathrm{Al}-$ 
cmolc $/ \mathrm{dm}^{3}$ ) and calculated the cation exchange (CTC $-\mathrm{cmolc} / \mathrm{dm}^{3}$ ), aluminum saturation ( $\mathrm{m} \%$ ) and base saturation $(\mathrm{V} \%)$, base sum $(\mathrm{S})$, and relation $\mathrm{Ca}: \mathrm{Mg}, \mathrm{Ca}: \mathrm{K}$ and $\mathrm{Mg}: \mathrm{K}$ (Santos et al., 2018).

To obtain the physical properties of the soil, we collected samples with volumetric rings of the Kopecky type of known volume, i.e. we collected three points per plot. After these collections, we stored and weighed the samples for later drying them in a drying kiln $\left(105^{\circ} \mathrm{C}\right)$. With these samples, we determined the soil humidity $(\%)$ through the volumetric method and total porosity (\%) and soil density $\left(\mathrm{g} \cdot \mathrm{cm}^{-3}\right)$ according to Teixeira et al. (2017).

To verify the luminosity condition of the arboreal stratum, we evaluated through the hemispherical photographies the canopy opening (Parker and Russ, 2004). In each plot we took four hemispherical photographs. We use a Nikon D3100 digital SLR camera and Nikon Fisheye Nikkor $10.5 \mathrm{~mm}$ lens. The camera was attached to a tripod and was facing the forest canopy at a height of $1.30 \mathrm{~m}$ from the ground (Silva, 2016). The photos were analyzed in the software Hemisfer 2.2 to obtain the values of canopy opening (\%) and leaf area $\left(\mathrm{m}^{2} \cdot \mathrm{m}^{2}\right)$ (Thimonier et al., 2010).

We obtained the elevation through a GPS Garmin 62CSx. We obtained the bioclimatic variables (Annual Mean Temperature, Mean Diurnal Range, Isothermality, Temperature Seasonality, Max Temperature of Warmest Month, Min Temperature of Coldest Month, Temperature Annual Range, Mean Temperature of Wettest Quarter, Mean Temperature of Driest Quarter, Mean Temperature of Warmest Quarter, Mean Temperature of Coldest Quarter, Annual Precipitation, Precipitation of Wettest Month, Precipitation of Driest Month, Precipitation Seasonality, Precipitation of Wettest Quarter, Precipitation of Driest Quarter, Precipitation of Warmest Quarter, Precipitation of Coldest Quarter), for each plot, in the data base of Fick and Hijmans (2017).

\section{Data analysis}

We calculated the values of relative density (\% individuals of a species in the community) and frequency (\% absolute frequency of a species in the community) through the phytosociological parameters described by Mueller-Dombois and Ellenberg (2002). During this process, we used the "spacemakeR" package in R environment ( R Core Team 2013), according to the recommendations of Borcard et al. (2011) and Eisenlohr (2014).

After that, we removed collinear environmental variables through principal component analysis (PCA) in PC-ORD 6.0 (McCune and Mefford, 2011). After this procedure, the environmental variables that remained in the analysis were clay content $(\mathrm{m} / \mathrm{v}-\%), \mathrm{pHH}_{2} \mathrm{O}, \mathrm{SMP}$ index, aluminum $\left(\mathrm{Al}-\mathrm{cmolc} / \mathrm{dm}^{3}\right)$, calcium $(\mathrm{Ca}-$ cmolc/dm $\left.{ }^{3}\right)$, magnesium $\left(\mathrm{Mg}-\mathrm{cmolc} / \mathrm{dm}^{3}\right)$, potassium $\left(\mathrm{K}-\mathrm{mg} / \mathrm{dm}^{3}\right)$, phosphorus $(\mathrm{P}-$ $\left.\mathrm{mg} / \mathrm{dm}^{3}\right)$, organic matter $(\mathrm{MO} \%)$, potential acidity $\left(\mathrm{H}+\mathrm{Al}-\mathrm{cmolc} / \mathrm{dm}^{3}\right)$, cation exchange (CTC $\left.-\mathrm{cmolc} / \mathrm{dm}^{3}\right)$, aluminum saturation ( $\left.\mathrm{m} \%\right)$, base saturation (V\%), base sum (S), and relation $\mathrm{Ca}: \mathrm{Mg}, \mathrm{Ca}: \mathrm{K}$ and $\mathrm{Mg}: \mathrm{K}$, soil humidity (\%), soil density $\left(\mathrm{g}_{\mathrm{cm}} \mathrm{cm}^{-3}\right.$, canopy opening $(\%)$, leaf area $\left(\mathrm{m}^{2} \cdot \mathrm{m}^{2}\right)$, elevation $(\mathrm{m})$, annual temperature $\left({ }^{\circ} \mathrm{C}\right)$ and annual precipitation ( $\mathrm{mm})$.

Subsequently, we used a species composition matrix. To correct the distinct units of measure, the environmental matrix was standardized ("standardized score transformation). The spatial matrix (MEMs) was established through the geographic coordinates (latitude and longitude). In this procedure we used the Environment R, with the package "spacemakeR" (Borcard et al., 2011). The MEMs (Moran's Eigenvector 
Maps) were selected through the "forward" method. The environmental variables were selected through the canonical analysis of RDA. Finally, the last RDA was processed in the PC-ORD 6.0 (McCune and Mefford, 2011), using the composition matrix with the environmental (standardized) and spatial (MEMs) variables selected to verify the effect of these variables in the distribution pattern of the species in the study site. The statistical significance of the RDA ordering axes was verified by means of 999 Monte Carlo permutations (Legendre and Legendre, 2012).

Then, we performed the partitioning of the variance into the data set in order to separate the fractions relative to the environment [a], the spatially structured environment [b], only the space [c] and the undetermined variables [d]. In this analysis, we used the "vegan", "packfor", "spacemakeR" and "spdep" packages in the R Environment (R Core Team 2013).

\section{Results}

In the 25 plots along the power transmission line, a total of 1,444 individuals (total absolute density $=1,925 \mathrm{ind} / \mathrm{ha}$ ) were sampled, belonging to 101 species and 38 botanic families (Table 1). The species with the highest density and frequency values were Cupania vernalis, Nectandra megapotamica, Sambucus australis, Trema micrantha, and Allophylus edulis.

Table 1. Species with the highest density and frequency values in the arboreal stratum adjacent to power transmission line in southern Brazil

\begin{tabular}{c|c|c|c}
\hline Family & Specie & DR & $\boldsymbol{F R}$ \\
\hline Sapindaceae & Cupania vernalis Cambess. & 12.9 & 5.9 \\
Lauraceae & Nectandra megapotamica (Spreng.) Mez & 6.4 & 5.9 \\
Adoxaceae & Sambucus australis Cham. \& Schltdl. & 6.3 & 2.6 \\
Cannabaceae & Trema micrantha (L.) Blume & 5.1 & 3.4 \\
Sapindaceae & Allophylus edulis (A.St.-Hil. et al.) Hieron. ex Niederl. & 5.1 & 4.6 \\
Malvaceae & Luehea divaricata Mart. \& Zucc. & 5.0 & 3.7 \\
Primulaceae & Myrsine umbellata Mart. & 4.8 & 3.7 \\
Lauraceae & Persea americana Mill. & 3.5 & 1.4 \\
Escalloniaceae & Escallonia bifida Link \& Otto & 3.4 & 0.6 \\
Fabaceae & Machaerium stipitatum Vogel. & 3.0 & 3.1 \\
Euphorbiaceae & Alchornea triplinervia (Spreng.) Müll.Arg. & 2.6 & 2.3 \\
Salicaceae & Casearia sylvestris (Vell.) Mart. & 2.4 & 4.0 \\
Meliaceae & Trichilia clausseni C.DC. & 2.1 & 1.7 \\
Rubiaceae & Psychotria suterella Müll.Arg. & 2.1 & 0.3 \\
Fabaceae & Parapiptadenia rigida (Benth.) Brenan & 1.8 & 3.1 \\
- & Others species & 33.5 & 53.7 \\
\hline- & Total & $\mathbf{1 0 0}$ & $\mathbf{1 0 0}$ \\
\hline
\end{tabular}

$\mathrm{DR}=$ relative density $(\%), \mathrm{FR}=$ relative frequency $(\%)$

In the redundancy analysis (RDA) (Figure 2, Table 2), the plots differed according to the variation in environmental and spatial variables. The eigenvalues of the first two ordering axes explained $14.6 \%$ of the data variance (axis $1=8.2 \%$, axis $2=6.4 \%$ ) and presented significance by the Monte Carlo test $(\mathrm{p} \leq 0.05)$. The environmental and spatial variables that correlated with axis 1 were MEM 1 and MEM 5, while for axis 2 were leaf area (LAI), elevation, Mg:K content and MEM 2. 

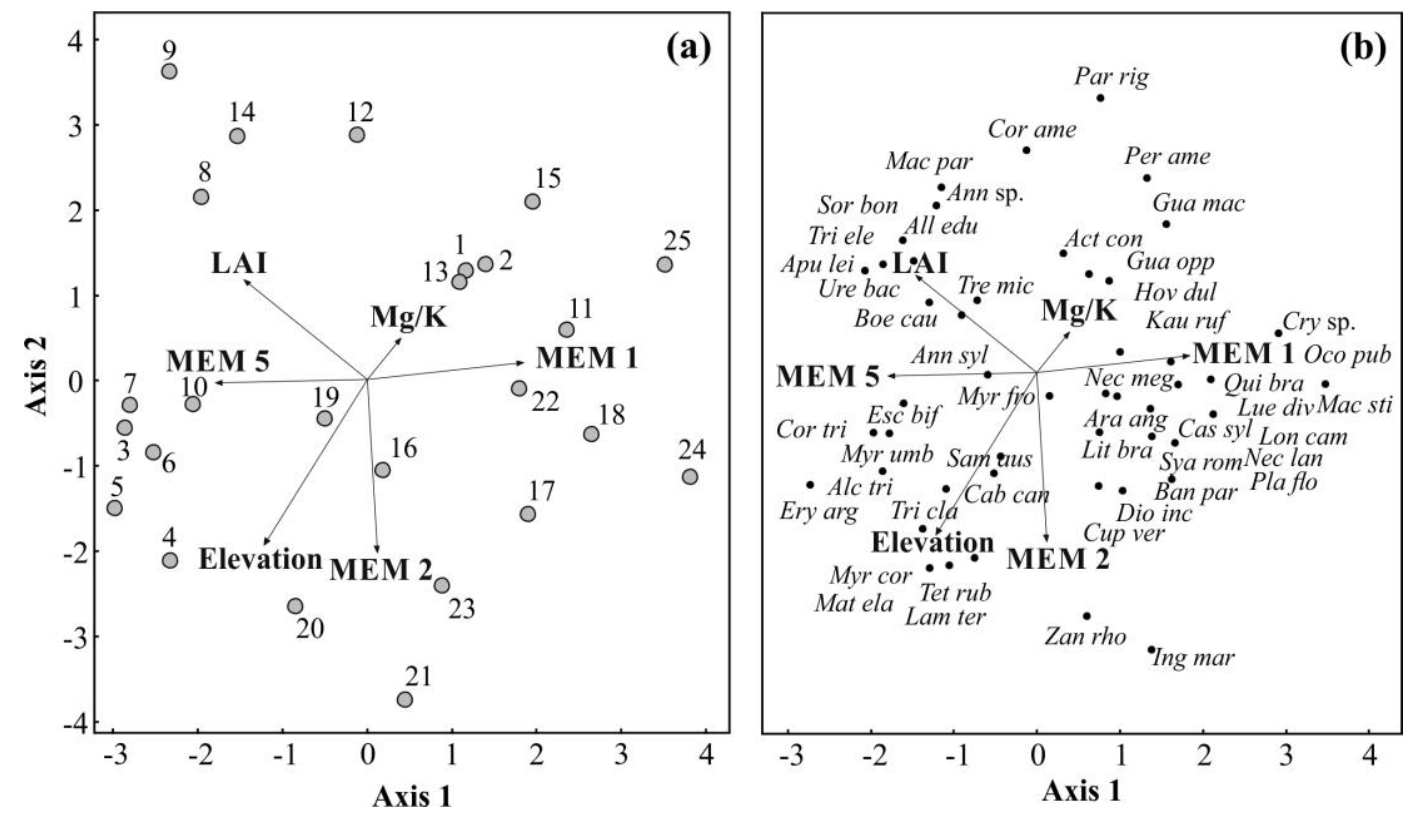

Figure 2. Redundancy analyzes (RDA) produced by plots, species and environmental and spatial variables in forest fragments under power transmission lines in southern Brazil

Table 2. Environmental and spatial variables produced by the RDA for forest fragments under power transmission lines in southern Brazil. $R^{2}$ adjusted, $F$ and $p$ were obtained by ANOVA after partitioning the variance

\begin{tabular}{c|c|c|c}
\hline Predictor & $\boldsymbol{R}^{\mathbf{2}}$ adjusted (\%) & $\boldsymbol{F}$ (ANOVA) & $\boldsymbol{p}$ (ANOVA) \\
\hline Elevation & 7.0 & 1.74 & 0.001 \\
MEM 1 & 5.8 & 1.41 & 0.02 \\
LAI & 5.7 & 1.45 & 0.02 \\
MEM 2 & 5.7 & 1.43 & 0.02 \\
MEM 5 & 5.6 & 1.43 & 0.02 \\
Mg/K & 5.5 & 1.42 & 0.01 \\
\hline
\end{tabular}

In the ordination diagram of the plots, we verified that the first two axes had a strong relation between area leaf and elevation and the spatial variable MEM 1, MEM 2 and MEM 5. The axes formed three groups of plots, the first one being related to the leaf area. These groups are influenced directly to the spatial variable MEM 5. The second group had strong relation with the elevation, and it was influenced by the spatial variable MEM 2. We verified the formation of a gradient between MEM 1 and the plots. In addition, we observed the formation of a short gradient related to the $\mathrm{Mg}: \mathrm{K}$ relation (Figure 2a).

In the diagram of species ordination, we verified a strong association with the leaf area and the density of arboreal individuals of Apuleia leiocarpa (Vogel) J.F.Macbr., Sorocea bonplandii (Baill.) W.C.Burger, Trichilia elegans A.Juss., Allophyllus edulis (Figure $2 b$ ), therefore, distinct levels of luminosity will affect the density of these species. While in areas with open canopy we found other predominant species, like Araucaria angustifolia (Bertol.) Kuntze, Nectandra megapotamica, Syagrus romanzoffiana (Cham) Glassman, Banara parviflora (A.Gray) Benth., Platymiscium floribundum Vogel. 
In the same sense, the formation of two gradients was observed between species with preference to soils with high $\mathrm{Mg}: \mathrm{K}$ relation and areas with low elevation (e.g., Actinostemon concolor (Spreng.) Müll.Arg., Persea americana, Guarea macrophylla Vahl., and Guapira opposita (Vell.) Reitz). The species associated with higher elevation are influenced directly by the spatial variable MEM 2. Thus, some biotic variation can influence directly on the species distribution. On the other hand, the species Sambucus australis Cham. \& Schltdl., Trichilia clausseni, Myrsine coriacea (Sw.) R.Br. ex Roem. \& Schult., and Matayba elaeagnoides Radlk, are associated to areas of higher elevation and lower $\mathrm{Mg} / \mathrm{K}$ relation.

Partitioning of variance revealed that fractions [a] "pure" environment $(F=1.34$, $p=0.007)$ and $[\mathrm{c}]$ "pure" space $(F=1.24, p=0.04)$ were significant (Figure 3). The fraction $[\mathrm{b}]$, related to space + environment, indicated that part of the analyzed environmental variables $(2 \%)$ is structured in space, while the [a] "pure" environment $(5 \%)$ and $[\mathrm{c}]$ "pure" space (3\%) stood out among fractions. However, the fraction [d] relative to the undetermined variables explained most of the vegetation variation in the study area $(90 \%)$.

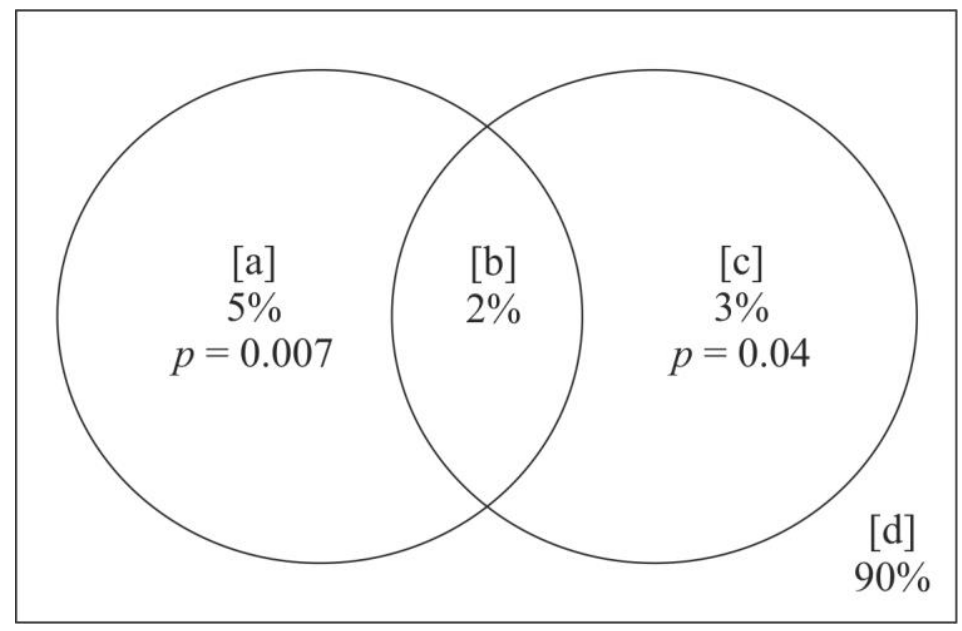

Figure 3. Partition of the variance by the redundancy analysis to determine the fractions "pure" environment [a], space + environment [b], "pure" space [c] and undetermined variables [d] for forest fragments under power transmission line in Southern Brazil

\section{Discussion}

In the present study we observed that some environmental variables have influence the distribution of species present in forest fragments adjacent to transmission lines. In addition, the spatial structure had a direct influence on the environmental variables, presenting a relevant role in the species distribution.

The elevation was the predictor that most influenced the distribution of the species. Studies indicate that elevation is an indirect environmental variable that influences vegetation distribution and characterization of forest types in the Atlantic Forest (Nettesheim et al., 2010; Maçaneiro et al., 2016; Duarte et al., 2019). In this study, not just the elevation has influence in the distribution of the species, but local features can directly influence the vegetation within the same altitudinal level (e.g., wind actions, watercourse) (Sanchez et al., 2013). Thus, higher elevation directly affects the floristic composition and, consequently, the maintenance of power transmission lines. 
We observed that Sambucus australis has high density in plots that were inserted in the highest elevation. Generally, this specie is in slopes areas (Grings and Brack, 2009). In this study, we identified a strong relation between the species distribution and the elevation variation, probably related to the environmental heterogeneity presenting in the power transmission line. In this same sense, the species distribution is associated to the elevation, luminosity and soil properties, granting predominance of certain species (Cardoso and Schiavini, 2002).

Considering the influence of the environmental variables in the present study, we observed that the leaf area positively affects the distribution of certain species (e.g., Apuleia leiocarpa, Sorocea bonplandii, Allophyllus edulis). The leaf area is associated with mass and energy changes, and is directly related to evapotranspiration, hydrology and ecology of the species (Wang et al., 2005; Galvani and Lima, 2014). Studies indicate that leaf area vary according to species composition, local conditions, successional stage, forest dynamics and light conditions, among others (Leblanc and Chen, 2008). According to Moraes et al. (2013), the leaf area is associated with ecological variations in the environment, influencing the productivity, growth, and reproduction of the species. Therefore, the application of the maintenance in species adapted to higher luminosity directly affects its growth and, consequently, if carried out in the vegetative period, the growth will be positively affected, increasing the cost and number of times to be performed the maintenance.

In the same way, the $\mathrm{Mg}: \mathrm{K}$ relation in the soil is associated with the presence of some species. In areas with more fertile soils, there are differences in floristic composition, density of dominant species, and lower fertility in the soil selects species with low nutritional requirements (Moreno et al., 2007). Unlike to the present study, floristic composition is generally associated with soil $\mathrm{pH}$, moisture, fertility and texture (Mélo et al., 2013). According to Maçaneiro et al. (2019), floristic richness increases in relation to water availability and soil depth. In this way, shallower soils may have lower floristic richness. In addition, nutritional availability will directly affect plant growth. Overall, the area exhibits high fertility rates affecting plant growth positively.

In addition to elevation, leaf area and $\mathrm{Mg}: \mathrm{K}$ content in the soil, the spatial factors were also predictors that influence the distribution of the species in fragments adjacent to power transmission lines. We observed that generally the spatial component is associated with the environmental variables that are related to the distribution of the species. We believe that it is possible that the soils variations, luminosity and elevation are conditioned to biotic and/or stochastic processes (e.g., such as dispersion and competition) (Diniz-Filho et al., 2012; Lewis et al., 2014). In this study the spatial component revealed a significant fraction on the floristic component, indicating the importance of the neutral processes on the vegetation.

In this study the distribution of Cupania vernalis is directly associated with biotic factors. This species presented the highest density and, therefore, is one of the species that must be taken into consideration for maintenance practices. This species is generally found in different topographic variations, but in higher density at high altitudes ( $700 \mathrm{~m}$ ) (Souza et al., 2015) and its growth is directly affected by the luminosity level (de Castro Lima et al., 2006). The association between the spatial predictor MEM 2 and elevation evidence that the specie can be observed in areas of higher elevation and it is being influenced of spatial component and linked to the altimetric quotes. 
The biotic variations are usually attributed to the spatial component, like the dispersion that provides different distribution patterns of species, such as anemocory that provides a random pattern, for example the fruits and seeds are distributed randomly in space (Urbanetz et al., 2003; Maçaneiro et al., 2018). The dispersion is among the most affected ecological processes in the life cycle of the plants, besides playing a fundamental role in the colonization and evolution of the species, it varies according to the elevation (Wang and Smith, 2002; Urbanetz et al., 2003; Almeida-Neto et al., 2008; Neuschulz et al., 2016). This justifies the relation of spatial factors to elevation, whereas the processes of facilitation and competition do not depend on the physical factors of the environment and on different climatic conditions (Mélo et al., 2013). Environments with more adversity (e.g., practice of maintenance of the vegetation) directly affects the species performance providing the facilitation process and acting like an ecological filter and influencing in the floristic composition (Temperton and Hobbs, 2004). Others processes that affect the species distribution are polinization and the seeds predation, being responsible for the species maintenance and presenting adversity for the establishment of the plants (Wang and Smith, 2002). Considering this, we observed that each specie has particularities, like polinization, dispersion, and it will be directly associated to the distribution and consequently to the density/frequency that the species will be found in certain place, influencing in the intensity of the maintenance of the power transmission line. In this case, the association of the spatial factors and environmental variables in the comprehension in how the vegetation is distributed in the power transmission line to determine the best maintenance practices (e.g., pruning intensity and cutting) which may avoid the fragmentation of the forests remnants and then reducing the costs for the electrical company.

The partitioning of the variance indicated that the highest percentage of factors that interfered in distribution patterns is related to unknown fractions (90\%). According to Lewis et al. (2014), variation of species composition along the plots and heterogeneity are factors that increase the unknown fractions. In addition, the environmental variables used are not necessarily the predictors that best explain the species distribution variations (Soininen, 2014). Another reason is the weakening of environmental responses when using a variance partition (Angeler et al., 2013). However, it revealed that purely environmental (5\%) and purely spatial (3\%) factors were statistically significant and could account for part of the distribution of species along in the power transmission line. The purely environmental fraction indicates that environmental variables are strongly related to the composition of species, while the purely spatial fraction presented a low explanation, justified by the high variation along the power transmission line. Nevertheless, the spatial component was significant in explaining species distribution patterns. In this sense, the inclusion of variables such as dispersion factors, water and light are necessary to determine the unknown fractions. In addition, the species respond interactively to environmental conditions, evidencing the complexity of the soil-plant-environment relationship (Siqueira et al., 2009).

Another hypothesis for the low environmental explanation is related to the maintenance practices that are performed in the vegetation adjacent to the transmission line, which may affect the forest structure and ensure greater homogeneity along the transmission line.

The spatially structured environment $(2 \%)$ affects the spatial distribution of the species, influencing where species are distributed, i.e., the greater the distances between 
the samples, the more floristic differences will be observed (Diniz-Filho et al., 2012). This fact is evidenced in the present study, since the power transmission lines cover an extension of $65 \mathrm{~km}$, that is, the sites sampled are generally separated at great distances, with a distinction being made between ecological sequences and floristic differences. The indeterminate variables presented high percentage, this fact occurred due to the great environmental heterogeneity and not to include all the variables that can act in the distribution of the species. Therefore, the inclusion of new biotic and abiotic factors would possibly increase the explanation of the variables on species distribution (Maçaneiro et al., 2016), or the inclusion of new plots to reduce floristic and site variability.

\section{Conclusion}

In our study, given the relationship found between vegetation and spatial/environmental variations, we suggested to perform selective maintenance in the vegetation. Thus, species such as Araucaria angustifolia, Nectandra megapotamica, Syagrus romanzoffiana, Banara parviflora, Platymiscium floribundum, which are associated with high luminosity should be managed with pruning or, if necessary, tree suppression, before reaching the height of risk. In addition to these species, Sambucus australis, Trichilia clausseni, Myrsine coriacea, Matayba elaeagnoides, which are associated with elevation, must also be managed when they reach the height of risk.

Although soil $(\mathrm{Mg}: \mathrm{K})$ ratio is associated with species distribution, due to homogeneity of soil fertility along the transmission line, this factor was not used as a criterion for species selection for maintenance. Given the difficulty of selective management, it is recommended at least to manage vegetation when it reaches 7 meters in height, thereby reducing the intensity of maintenance of areas under power transmission lines, minimizing costs with this activity. and minimizing the impacts generated.

In addition, this study was developed on a local scale, in this sense, we suggest the development of other studies with complementary information such as competition, dispersion and microclimate, since the addition of these variables can increase the predictive power of floristic patterns in subtropical forests, and offers indicators to improve or plan the management of native forests under electric power lines.

Acknowledgements. The authors are grateful to Coordenação de Aperfeiçoamento de Pessoal de Nivel Superior (CAPES) and Conselho Nacional de Desenvolvimento Científico e Tecnológico (CNPq) for their research fellowship grant. We also thank Luiz Henrique da Silva from FURB Idiomas for English review.

\section{REFERENCES}

[1] Ahmad, J., Malik, A. S., Abdullah, M. F., Kamel, N., Xia, L. (2014): A novel method for vegetation encroachment monitoring of transmission lines using a single $2 \mathrm{D}$ camera. Pattern analysis and applications 18(2): 419-440.

[2] Almeida-Neto, M., Campassi, F., Galetti, M., Jordano, P., Oliveira-Filho, A. T. (2008): Vertebrate dispersal syndromes along the Atlantic forest: broad-scale patterns and macroecological correlates. - Global Ecology and Biogeography 17(4): 503-513. 
[3] Alvares, C. A., Stape, J. L., Sentelhas, P. C., Gonçalves, J. L. M., Sparovek, G. (2013): Köppen's climate classification map for Brazil. - Meteorologische Zeitschrift 22(6): 711728.

[4] Angeler, D. G., Göthe, E., Johnson, R. K. (2013): Hierarchical dynamics of ecological communities: do scales of space and time match? - PLoS One 8(7): e69174.

[5] Borcard, D., Gillet, F., Legendre, P. (2011): Numerical Ecology with R. - Dordrecht London Heidelberg, New York.

[6] Cardoso, E., Schiavini, I. (2002): Relationship between tree species distribution and topography in a forest gradient in the Panga Ecological Station (Uberlândia, MG). Brazilian Journal of Botany 25(3): 277-289. [Portuguese].

[7] de Castro Lima Jr., É., de Alvarenga, A. A., de Castro, E. M., Vieira, C. V., Barbosa, J. P. R. A. D. (2006): Aspectos fisioanatômicos de plantas jovens de Cupania vernalis Camb. Submetidos a diferentes níveis de sombreamento. - Revista Árvore 30(1).

[8] Diniz-Filho, J. A. F., Siqueira, T., Padial, A. A., Rangel, T. F., Landeiro, V. L., Bini, L. M. (2012): Spatial autocorrelation analysis allows disentangling the balance between neutral and niche processes in metacommunities. - Oikos 121(2): 201-210.

[9] Duarte, S. W., Hoffmann, L. T., Maçaneiro, J. P., Fenilli, T. A. B., Schorn, L. A. (2019): Effects of the environment and spatial factors on the regeneration of Araucaria Forest fragments, southern Brazil. - Applied Ecology and Environmental Research 17(4): 95779589.

[10] Dupras, J., Patry, C., Tittler, R., Gonzalez, A., Alam, M., Messier, C. (2015): Management of vegetation under electric distribution lines will affect the supply of multiple ecosystem services. - Land Use Policy 51: 68-75.

[11] Eisenlohr, P. V. (2014): Persisting challenges in multiple models: a note on commonly unnoticed issues regarding collinearity and spatial structure of ecological data. - Brazilian Journal of Botany 37: 365-371.

[12] Fick, S. E., Hijmans, R. J. (2017): Worldclim 2: New 1-km spatial resolution climate surfaces for global land areas. - International Journal of Climatology 37: 4302-4315.

[13] Galvani, E., Lima, N. G. B. (2014): Hemispherical photographs in microclimatic studies: theoretical-conceptual and applications. - Ciência e Natura 36: 215-221. [Portuguese].

[14] Grings, M., Brack, P. (2009): Trees in the native vegetation of Nova Petrópolis, Rio Grande do Sul. - Iheringia 64(1): 5-22. [Portuguese].

[15] Jurinitz, C. F., Oliveira, A. A., Bruna, E. M. (2013): Abiotic and Biotic Influences on Early-Stage Survival in Two Shade-Tolerant Tree Species in Brazil's Atlantic Forest. Biotropica 45(6): 728-736.

[16] Kuntz, P. A., Christie, R. D., Venkata, S. S. (2002): Optimal maintenance scheduling of overhead electric power distribution systems. - IEEE Transactions on power delivery 17(4): 1164-1169.

[17] Leblanc, S. G., Chen, J. M. (2008): A practical scheme for correcting multiple scattering effects on optical LAI measurements. - Agricultural Forest Meteorological 110(2): 125139.

[18] Legendre, P., Legendre, L. (2012): Numerical ecology. - Elsevier, Amsterdam, Netherlands.

[19] Lewis, R. J., Pakeman, R. J., Marrs, R. H. (2014): Identifying the multi-scale spatial structure of plant community determinants of an important national resource. - Journal of Vegetation Science 25(1): 184-197.

[20] Lopes, R. F. (2013): Optimization of maintenance process in border zone of medium / high power lines. - Faculdade de Engenharia da Universidade do Porto, Porto, MSc Thesis. [Portuguese].

[21] Maçaneiro, J. P., Oliveira, L. Z., Seubert, R. C., Eisenlohr, P. V., Schorn, L. A. (2016): More than environmental control at local scales: do spatial processes play an important role on floristic variations in Subtropical Forests? - Acta Botanica Brasilica 30(2): 183192. 
[22] Maçaneiro, J. P., Gasper, A. L., Galvão, F., Schorn, L. A. (2018): Dispersion and aggregation patterns of tree species in Araucaria Forest, Southern Brazil. - Anais da Academia Brasileira de Ciências 90(2): 2397-2408.

[23] Maçaneiro, J. P., Liebsch, D., Gasper, A. L., Galvão, F., Schorn, L. A. (2019): Structural and floristic variations in an Atlantic Subtropical Rainforest in Southern Brazil. - Floresta e Ambiente 26(1): e20160101.

[24] Matikainen, L., Lehtomäki, M., Ahokas, E., Hyypä, J., Karjalainen, M., Jaakkola, A., Kukko, A., Heinonen, T. (2016): Remote sensing methods for power line corridor surveys. - ISPRS Journal of Photogrammetry and Remote Sensing 119: 10-31.

[25] McCune, B., Mefford, M. J. (2011): PC-ORD: Multivariate analysis of ecological data, Version 6. - MjM Software Design. Gleneden Beach, Oregon.

[26] Mélo, M. A., Budke, J. C., Henke-Oliveira, C. (2013): Relationships between structure of the tree component and environmental variables in a subtropical seasonal forest in the upper Uruguay River valley, Brazil. - Acta Botanica Brasilica 27(4): 751-760.

[27] Moraes, L., Santos, R. K., Wisser, T. Z., Krupek, R. A. (2013): Evaluation of leaf area from simple linear measurements of five plant species under different light conditions. Revista Brasileira de Biosciências 11(4): 381-387. [Portuguese].

[28] Moreno, M. I. C., Schiavini, I., Haridasan, M. (2007): Influence of the edaphic factors in the Cerrado fitofisionomies. - Caminhos da Geografia 9(25): 173-194. [Portuguese].

[29] Mueller-Dombois, D., Ellenberg, H. (2002): Aims and methods of vegetation ecology. The Blackburn Press, New Jersey, USA.

[30] Nettesheim, F. C., Menezes, L. F. T., Carvalho, D. C., Conde, M. M. S., Araújo, D. S. D. (2010): Influence of environmental variation on Atlantic Forest tree-shrub-layer phytogeography in southeast Brazil. - Acta Botanica Brasilica 24(2): 369-377.

[31] Neuschulz, E. L., Mueller, T., Schleuning, M., Böhning-Gaese, K. (2016): Pollination and seed dispersal are the most threatened processes of plant regeneration. - Scientific Reports 6(29839).

[32] Parker, G. G., Russ, M. (2004): The canopy surface and stand development: assessing forest canopy structure and complexity with near-surface altimetry. - Forest Ecology and Management 189(1-3): 1284-1307.

[33] R Core Team. (2013): R: A language and environment for statistical computing. Vienna: R Foundation for Statistical Computing.

[34] Ribeiro, M. C., Martensen, A. C., Metzger, J. P., Tabarelli, M., Scarano, F., Fortin, M. J. (2011): The Brazilian Atlantic forest: a shrinking biodiversity hotspot. - In: Zachos, F. E., Habel, J. C. (eds.) Biodiversity hotspots. Springer, Heidelberg.

[35] Rocha, R. P., Silva, M. B. (2013): Biogeographical History of the Atlantic Forest: Opilioes (Arachnida) as a model for their inference. - In: Carvalho, C. J. B., Almeida, E. A. B. (eds.) Biogeography of South America: Standards and processes. Roca, São Paulo, Brasil. [Portuguese].

[36] Sanchez, M., Pedroni, F., Eisenlohr, P. V., Oliveira-Filho, A. T. (2013): Changes in tree community composition and structure of Atlantic rain forest on a slope of the Serra do Mar range, Southeastern Brazil, from near sea level to $1000 \mathrm{~m}$ of altitude. - Flora 208(3): 184-196.

[37] Santos, H. G., Jacomine, P. K. T., Anjos, L. H. C., Oliveira, V. A. V., Lumbreras, J. F., Coelho, M. R., Almeida, J. A., Cunha, T. J. F., Oliveira, J. B. (2018): Brazilian system of soil classification. - Embrapa, Distrito Federal. [Portuguese].

[38] Scipioni, M. C., Galvão, F., Longhi, S. J. (2013): Floristic composition and dispersal and regeneration strategies of woody species in Deciduous Seasonal Forests. - Floresta 43(2): 241-254. [Portuguese].

[39] Silva, D. A. (2016): Effect of harvest intensity on the remaining structure of a secondary forest managed in Guaramirim-SC. - Universidade Regional de Blumenau, Blumenau, MsC Thesis. [Portuguese]. 
[40] Silverio Neto, R., Bento, M. C., Menezes, S. J. M. C., Almeida, F. S. (2015): Characterization of Forest Cover of Protected Areas of the Atlantic Forest. - Floresta e Ambiente 22(1): 32-41. [Portuguese].

[41] Siqueira, A. S., Araújo, G. M., Schiaviani, I. (2009): Tree layer structure and soil characteristics of two deciduous dry forests in the Araguari river valley, Minas Gerais State, Brazil. - Acta Botanica Brasilica 23(1): 10-21. [Portuguese].

[42] Soininen, J. (2014): A quantitative analysis of species sorting across organisms and ecosystems. - Ecology 95(12): 3284-3292.

[43] Souza, K., Souza, C. C., Rosa, M. G., Cruz, A. P., Lima, C. L., Silva, J. O., Lazzarin, L. C., Loebens, R., Dias, R. A. R., Silva, A. C., Higuchi, P., Schimalski, M. B. (2015): Tree component structure and dispersion strategies in a subtropical forest along a topographic sequence in Alto- Uruguai. - Scientia Forestalis 43(106): 321-332. [Portuguese].

[44] Teixeira, P. C., Donagemma, G. K., Fontana, A., Teixeira, W. G. (2017): Manual of soil analysis methods. - Embrapa, Brasília. [Portuguese].

[45] Temperton, V. M., Hobbs, R. J. (2004): The search for ecological assembly rules and its relevance to restoration ecology. - In: Temperton, V. M., Hobbs, R. J., Nuttle, T., Halle, S. (eds.) Assembly rules and restoration ecology: brindging the gap between theory and practice. Island Press, New York.

[46] Thimonier, A., Sedivy, I., Schleppi, P. (2010): Estimating leaf area index in different types of mature forest stands in Switzerland: a comparison of methods. - European Journal of Forest Research 129(4): 543-562.

[47] Urbanetz, C., Oliveira, V. M., Raimundo, R. L. G. (2003): Spatial pattern and dispersion syndromes. - www2.ib.unicamp.br/profs/fsantos/relatorios/ne211r3a2003.pdf. (accessed on 20.05.2019). [Portuguese].

[48] Wang, B. C., Smith, T. B. (2002): Closing the seed dispersal loop. - Trends in Ecology and Evolution 17(8): 379-386.

[49] Wang, Q., Adiku, S., Tenhunen, J., Granie, R. A. (2005): On the relationship of NDVI with leaf area index in a deciduous forest site. - Remote Sensing of Environment 94(2): 244-255.

[50] Young, R. F. (2010): Managing municipal green space for ecosystem services. - Urban forestry and urban greening 9(4): 313-321. 